\title{
A Note on Federal Reserve Policy Incongruencies
}

\author{
William Carlson ${ }^{*}$, Conway Lackman² \\ ${ }^{1}$ Duquesne University (ret.), Pittsburgh, PA, USA \\ ${ }^{2}$ Duquesne University (ret.) and Intl. Consulting Group, Pittsburgh, PA, USA \\ Email: cllackman@gmail.com
}

Received 21 October 2015; accepted 15 December 2015; published 21 December 2015

Copyright (C) 2015 by authors and Scientific Research Publishing Inc.

This work is licensed under the Creative Commons Attribution International License (CC BY).

http://creativecommons.org/licenses/by/4.0/

(c) $\underset{\mathrm{EY}}{\mathrm{B}}$ Open Access

\begin{abstract}
The incongruencies of Federal Reserve (Fed) policy is demonstrated where the Fed proposes to raise interest rates on excess reserves claiming that generally rising rates that follow will help households increase interest income. The resulting slowing of the economy, however, will cause slowing employment and income gains which are likely to more than offset any rising interest income.
\end{abstract}

Keywords

Monetary Policy, Fed Interest Rate and Excess Reserves Policy

\section{Introduction}

In a low visibility maneuver, the Fed installed a policy to pay interest (IOER) on excess reserves with an amendment to EESA, 2008, reported in H.3 Statistical Release which the Fed considered eliminating, but has not yet done so. The policy was designed but not proven to give the Fed better monetary control. However, it does not impact the monetary base which is the control source hence this policy's effectiveness is unlikely. Moreover, Bloomberg [1] among others objected to the ramifications that this policy would result in payments to member banks (mostly the largest 100 banks) of $\$ 77$ bil. in interest this year. And, if interest rates follow the Fed's highest path forecast and reach $4.5 \%$, the Fed will pay out $\$ 112.4$ bil. The issue gets more critical as the probability of the Fed raising interest rates (federal funds rate) increases. The Fed cannot stimulate the economy still recovering a lower level than growth rate trend line by raising rates and encouraging de facto hoarding.

${ }^{*}$ Corresponding author.

How to cite this paper: Carlson, W. and Lackman, C. (2015) A Note on Federal Reserve Policy Incongruencies. Modern Economy, 6, 1235-1239. http://dx.doi.org/10.4236/me.2015.612116 


\section{Policy Issue}

One wonders how a policy like this which encourages de facto hording, i.e. rates rise, more bank funds are put into excess reserves, could stimulate to the economy, when the opposite would result, i.e. more hording, less lending, slower economic growth needs to come under scrutiny. Fed officials are only just realizing the risks that such a policy imposes. The Fed paid banks $\$ 4$ bil. last year, about $\$ 12$ per American Bloomberg quoting Professor David Howden. William Dudley president of the New York Fed had incongruously argued that these interest payments on excess reserves are "not a subsidy for banks. Deposit rates (that benefits households) will rise with interest rates”. In Hilsinrath's blog [2] (9/28/15), Dudley propones an argument for discretionary vs. rules decision making, flying in the face of Milton Friedman and other monetary experts, in that the former better accounts for expectations in the economy. That is highly debatable but beyond the scope of this topic.

\section{Consequences of Policy Error}

Under Quantitative Easing (QE2-the large scale asset purchase program) the Fed drove system excess reserves up to $\$ 1.7$ tril. Fed balance sheet will reach $\$ 4$ Tril. by the year end with excess reserves at $\$ 2.5$ tril. The Fed can't have it both ways. Dudley's household gains from higher interest rates will slow economic growth forcing some households to trade in their jobs for a little more interest income. Equally important is the practical matter that the Fed does not have enough short term securities (liquidity) to cover such interest payments on excess reserves. Finally, the Treasury facing record debt burdens will not receive any funds from this operation.

\section{Policy Correction}

The money stock plays an important role in explaining some economic events. Here is a quick derivation of the formula. Divide $\mathrm{M} 1=\mathrm{Cp}+\mathrm{Dp}$ by $\mathrm{Ba}=\mathrm{Cp}+\mathrm{Rr}+\mathrm{Re}$ then multiply by $\mathrm{Ba}$. The result is

$\mathrm{M} 1=[\mathrm{Cp}+\mathrm{Dp} / \mathrm{Cp}+\mathrm{Rr}+\mathrm{Re}] \mathrm{Ba}$ where the term in the bracket is the money multiplier. Now divide the numerator and denominator of the money multiplier by $\mathrm{Dp}$ and let $\mathrm{Cp} / \mathrm{Dp}=\mathrm{k}, \mathrm{Dp} / \mathrm{Dp}=1, \mathrm{Rr} / \mathrm{Dp}=\mathrm{rr}$, and $\mathrm{Re} / \mathrm{Dp}=\mathrm{re}$, and substitute. Then $\mathrm{M} 1=(1+\mathrm{k} / \mathrm{k}+\mathrm{rr}+\mathrm{re}) \mathrm{Ba}$. The quantity in the parentheses is the money multiplier. In normal times the multiplier is reasonably constant.

Normally the currency/deposit ratio $\mathrm{k}$ is constant in the short run, drifting with payment habits and innovations. It does rise in times of financial panic such as the waves of bank failures 1930-33 as people literally took money out of banks and put it under the mattress.

The required reserve ratio is basically determined by state and Federal Reserve requirements (Regulation D). Since reserve requirements vary according to deposit classification (demand, Passbook savings, and different kinds of CDs), rr is also determined by the deposit mix. In the July 1980 Federal Reserve Bulletin p. A-8 shows 12 different categories of deposits. Fortunately rr has been relatively stable since the disastrous 1936-7 episode. Normally, re is near zero because before 2008 excess reserves earned no interest. In the 1920s re was below.01, rose to 0.03 in the first quarter of 1933 at the bottom of the Great Depression, and jumped to 0.10 in 2Q34 when the zero interest rate bound was approached [3].

The monetary base $\mathrm{Ba}$ is the legal tender held by the public (currency held by the public $\mathrm{Cp}$ ) and reserves of depository institutions mainly banks. Bank holdings of legal tender equivalents are called reserves R. Some reserves are held as vault cash but most reserves are deposited at Federal Reserve banks. In equation form $\mathrm{Ba}=\mathrm{Cp}$ $+\mathrm{R}$. The Federal Reserve can manage the monetary base with a simple method called open market operations. Suppose the Fed wants to increase the base (and implicitly the money stock M1 which is Cp plus demand deposits Dp: M1 = Cp + Dp). It buys Treasury bills, notes, or bonds from the public and/or banks and pays the public and/or banks in cash directly or indirectly. This increases Ba. To reduce Ba the Fed sells Treasuries to the public and/or banks and is paid in cash or cash equivalents reducing the base.

The Fed needs to eliminate this policy incongruency by eliminating the IOER and focusing on the monetary base. Moreover, the Fed will need to rebalance its portfolio trading longs for shorts. In the tables below, we show an efficient way of accomplishing this. The Fed as of 9/23/15 held only about $\$ 330$ mil. in short term securities ( $0.06 \%$ of total treasuries) compared to about $\$ 221$ bil. on $12 / 31 / 06$ or $28.43 \%$ of total Treasuries (Table 1).

Our Solution 1 is to rebalance about $\$ 1.26$ bil. of long terms into short term securities ( $26.48 \%$ of treasuriesTable 2). The Fed would have plenty of T-bills to sell in a classic Open Market Operation (OMO) to raise short 
Table 1. Fed balance sheets.

\begin{tabular}{|c|c|c|c|c|c|c|c|}
\hline \multicolumn{8}{|l|}{$\begin{array}{l}\text { Sept. 23, } 2015 \text { H.4.1 Release } \\
\text { Assets (bil, \$) }\end{array}$} \\
\hline Au SDA coin & \multicolumn{2}{|c|}{18,144} & Maturity & Treasuries & Agency & MBS & Total \\
\hline Prems, Disct, Loans & \multicolumn{2}{|c|}{177,625} & 0 - 15 day & 0.001 & & & 0.001 \\
\hline Repos & \multicolumn{2}{|c|}{0} & $16-90$ & 0.327 & 2.149 & & 2.476 \\
\hline Securities & \multicolumn{2}{|c|}{$4,249,658$} & $91-1$ yr. & 166.971 & 12.45 & & 179.423 \\
\hline Misc. & \multicolumn{2}{|c|}{52,057} & 1 - 5 yr. & 1133.906 & 18.14 & 0.151 & 1152.20 \\
\hline \multirow[t]{2}{*}{ Total } & \multicolumn{2}{|c|}{$4,497,484$} & 5 - 10 yr. & 522.712 & & 9.506 & 532.218 \\
\hline & & & $10+$ yr. & 638.04 & 2.347 & 1742.9 & 2383.3 \\
\hline Liabilities and New Worth & & & Total & 2461.957 & 35.09 & 1752.6 & 4249.6 \\
\hline \multicolumn{8}{|c|}{ Note: Only $0.06 \%$ of portfolio in shorts } \\
\hline Reverse Repos & \multicolumn{2}{|c|}{303,797} & & & & & \\
\hline Currency & \multicolumn{2}{|c|}{$1,339,843$} & & & & & \\
\hline Bank Reserves & \multicolumn{2}{|c|}{$2,767,137$} & & & & & \\
\hline Misc & \multicolumn{2}{|c|}{28,155} & & & & & \\
\hline Capital & \multicolumn{2}{|c|}{58,552} & & & & & \\
\hline Total & \multicolumn{2}{|c|}{$4,497,484$} & & & & & \\
\hline \multicolumn{8}{|l|}{ Dec. 31, 2006} \\
\hline \multicolumn{8}{|l|}{ Assets (bil, \$) } \\
\hline $\mathrm{Au}$ SDA coin & & 14,038 & Maturity & Treasuries & Agency & MBS & Total \\
\hline Prems, Disct, Loans & & 8258 & 0 - 15 day & 40750 & & & 40.588 \\
\hline Repos & & & $16-90$ & 180.893 & 2.149 & & 183.042 \\
\hline Securities & & 778,914 & $91-1$ yr. & 185.132 & 12.452 & & 197.584 \\
\hline Misc. & & 31,404 & 1 - 5 yr. & 224.177 & 18.145 & 0.151 & 242.473 \\
\hline \multirow[t]{2}{*}{ Total } & & 873,364 & $5-10$ yr. & 67.645 & & 9.506 & 77.151 \\
\hline & & & $10+\mathrm{yr}$. & 80.479 & 2.347 & 1742.962 & 1825.788 \\
\hline Liabilities and New Worth & Total & 778.914 & 35.093 & 1752.619 & 2566.626 & & \\
\hline \multicolumn{8}{|c|}{ Note: $28.43 \%$ of portfolio in shorts } \\
\hline Reverse Repos & & 29,615 & & & & & \\
\hline Currency & & 783,019 & & & & & \\
\hline Bank Reserves & & 18,699 & & & & & \\
\hline Misc & & 11,383 & & & & & \\
\hline Capital & & 30,648 & & & & & \\
\hline Total & & 873,364 & & & & & \\
\hline
\end{tabular}


Table 2. Solution 1-T-bill-T-bond Swap with Treasury (swap half of 1 - 10 yr for T-bills).

\begin{tabular}{|c|c|c|c|c|c|}
\hline \multicolumn{6}{|l|}{ Sept. 23, 2015 H.4.1 Release } \\
\hline Au SDA coin & 18,144 & Maturity & Treasuries & Agency & MBS \\
\hline Prems, Disct, Loans & 177,625 & 0 - 15 day & 0.001 & & \\
\hline Repos & 0 & $16-90$ & 1123132 & 2.149 & \\
\hline Securities & $4,249,658$ & 91 - 1 yr. & 83785 & 12.452 & \\
\hline Misc. & 52,057 & 1 - 5 yr. & 566953 & 18.145 & 0.151 \\
\hline Total & $4,497,484$ & 5 - 10 yr. & 261356 & & 9.506 \\
\hline Note: Fed has ample T bills to & & $10+$ yr. & 319020 & 2.347 & 1742.962 \\
\hline do OMO to raise short term rates. & & Total & 2353939 & 35.093 & 1752.619 \\
\hline \multicolumn{6}{|l|}{$0.06 \%$ of portfolio in shorts } \\
\hline \multicolumn{6}{|l|}{ Liabilities and New Worth } \\
\hline Reverse Repos & 303,797 & & & & \\
\hline Currency & $1,339,843$ & & & & \\
\hline Bank Reserves & $2,767,137$ & & & & \\
\hline Misc & 28,155 & & & & \\
\hline Capital & 58,552 & & & & \\
\hline Total & $4,497,484$ & & & & \\
\hline
\end{tabular}

Note: Fed cannot do open market transaction without short term treasuries.

Table 3. Solution 2-Fed issues its own equivalent of 3 mo. T-bill.

\begin{tabular}{|c|c|c|c|c|c|c|}
\hline \multicolumn{7}{|l|}{ Assets (bil, \$) } \\
\hline Au SDA coin & 18,144 & Maturity & Treasuries & Agency & MBS & Total \\
\hline Prems, Disct, Loans & 177,625 & 0 - 15 day & 0.001 & & & 0.001 \\
\hline Repos & 0 & $16-90$ & 2000327 & 2.149 & & 2000329 \\
\hline Securities & $4,249,658$ & 91 - 1 уг. & 166971 & 12.452 & & 166983.5 \\
\hline 3 mo Fed T-bills & $2,000,000$ & $1-5 \mathrm{yr}$ & 1133906 & 18.145 & 0.151 & 1133924 \\
\hline Misc. & 52,057 & $5-10 \mathrm{yr}$. & 522712 & & 9.506 & 522721.5 \\
\hline \multirow[t]{2}{*}{ Total } & $6,497,484$ & $10+$ yr. & 638040 & 2.347 & 1742.962 & 639785.3 \\
\hline & & Total & 4461956 & 35.093 & 1752.619 & 4461956 \\
\hline \multicolumn{7}{|c|}{$\begin{array}{l}\text { Note: Fed has ample } \\
\text { T-Bills to sell in OMO to raise } \\
\text { short term rates. }\end{array}$} \\
\hline \multicolumn{7}{|c|}{$32.04 \%$ of portfolio in shorts vs. $0.06 \%$} \\
\hline \multicolumn{7}{|c|}{ Liabilities and New Worth } \\
\hline Reverse Repos & 303,797 & & & & & \\
\hline Currency & $1,339,843$ & & & & & \\
\hline Bank Reserves & $2,767,137$ & & & & & \\
\hline Short term debt & $2,000,000$ & & & & & \\
\hline Misc & 28,155 & & & & & \\
\hline Capital & 58,552 & & & & & \\
\hline Total & $6,497,484$ & & & & & \\
\hline
\end{tabular}


term rates and cover IOER). Our Solution 2 is to rebalance totally into 16 - 90 days bills at just over $\$ 2$ tril. (32.04\% of treasuries-Table 3), again providing T-bills to conduct OMO.

\section{Recommendation}

Solution 1 is arguably more balanced in that it uses two vs. one maturity classification of assets to conduct OMO. However, a better policy would be to abandon the IOER tool and focus on the monetary base to control the money supply consistent with sound economic theory and policy. Moreover, with Solution 2, banks get a return on treasuries rather than a gift from the Fed and hoarding is avoided which prevents a slowdown in economic growth.

\section{References}

[1] http://www.bloomberg.com/new/articles/2013-04-15/fed-seenpayin

[2] https://us-mg5.yahoo.com/neo/b/messge?sMid=10\&fid-Inbox

[3] Board of Governors of the Federal Reserve System (2013) Aggregate Reserves of Depository Institutions and the Monetary Base, 2013. 